\title{
EFEKTIVITAS PENGGUNAAN EKSTRAK ANTOSIANIN TANAMAN BUNGA KEMBANG SEPATU UNTUK MENDETEKSI BORAKS PADA BAKSO
}

\author{
Rio Purnama ${ }^{1}$, Septri Andriani Jose ${ }^{2}$ \\ ${ }^{1,2}$ Fakultas Teknologi Kesehatan, Institut Ilmu Kesehatan dan Teknologi Muhammadiyah Palembang \\ email: rio.purnama1210@gmail.com
}

\begin{abstract}
One of the causes of food safety problems in Indonesia is the lack of knowledge, responsibility and supervision by producers, consumers and the authorities. This results in cheating by irresponsible food producers, adding ingredients that can harm the human body. There are several ways to detect or detect the presence of hazardous food additives, one of which is using indicators made from natural ingredients added with several other ingredients that can detect hazardous food additives, one of which is borax. After conducting research on the effectiveness of hibiscus flower anthocyanin extract as an indicator of borax detection in meatballs, it was found that hibiscus flower extract can be used as an indicator for borax detection, seen from the change in the color of hibiscus flower extract which at first is brownish orange (purplish. ) After being absorbed with meatballs containing borax, the hibiscus flower extract changes its color to dark brown red, this is due to the pelagornidin antasianin compounds reacting with borax compounds.
\end{abstract}

Keywords: Borax, Anthocyanin Exstract, meatball

\section{PENDAHULUAN}

Indonesia merupakan negara yang mempunyai peluang besar menjadi lumbung pangan Asean dan Asia Tenggara, dan bukan tidak mungkin rencana yang disusun pemerintah untuk menjadikan Indonesia sebagai lumbung pangan dunia akan terwujud, Namun disisi lain masyarakat Indonesia yang seharusnya memiliki tanggung jawab besar untuk mengawasi serta menjaga kesehatan pangan yang ada disekelilingnya, serta dibantu oleh pihak berwenang untuk mengatur kesehatan dan keamanan pangan yang ada malah seringkali tidak menjalankan perannya dengan benar, ditambah lagi produsen pangan yang sebaiknya lebih bertanggung jawab serta mampu menjaga dan memastikan keamanan pangan yang dihasilkan. ${ }^{1}$

Masalah keamanan pangan yang ada di Indonesia salah satu penyebabnya merupakan kurangnya pengetahuan, tanggung jawab, dan pengawasan oleh produsen, konsumen, dan pihak berwenang. Hal ini menyebabkan adanya kecurangan yang dilakukan oleh produsen pangan tidak bertanggung jawab, yang menambahkan bahan-bahan yang dapat membahayakan tubuh manusia. Bahan berbahaya yang ditambahkan antara lain yaitu bahan kimia yang sangat berdampak buruk bagi kesehatan manusia bahkan bisa menyebabkan kematian. ${ }^{1}$

Setiap hari kita membutuhkan makanan untuk mendapatkan energi, memperbaiki sel-sel yang rusak, pertumbuhan, menjaga suhu dan kondisi badan tidak terserang penyakit. Makanan yang bergizi merupakan makanan yang mengandung karbohidrat, lemak, protein, vitamin, mineral, dan air. Sehat tidaknya suatu makanan tidak bergantung pada ukuran, bentuk, warna, kelezatan, aroma, atau kesegarannya, tetapi tergantung pada kandungan zat gizi yang diperlukan oleh tubuh. Suatu makanan dikatakan sehat apabila mengandung satu macam atau lebih zat gizi yang diperlukan oleh tubuh. Setiap hari, kita perlu mengkonsumsi makanan yang beragam agar semua jenis zat gizi yang diperlukan oleh tubuh terpenuhi. Hal ini dikarenakan tidak ada satu jenis 
makanan yang mengandung semua jenis dan jumlah zat gizi yang diperlukan oleh tubuh setiap hari. ${ }^{2}$

Bahan tambahan pangan (BTP) juga biasa disebut dengan zat adiktif makanan, food additive, bahan kimia makanan, atau bahan tambahan makanan. ${ }^{2}$ Bahan makanan yang berbahaya yang sering digunakan di Indonesia salah satunya adalah boraks. Banyaknya issue makanan yang mengandung boraks sangat meresahkan masyarakat. Disisi lain dengan tingkat kesadaran masyarakat masih relative rendah dibidang kesehatan. Sehingga penggunaan zat tambahan yang tidak layak dikonsumsi semakin meningkat dengan ketidaktahuan para produsen dan konsumen. ${ }^{1}$

Pada tahun 2002, masyarakat dikejutkan oleh adanya penelitian dari Badan Pengawasan Obat dan Makanan yang menemukan adanya kandungan zat pengawet berbahaya seperti boraks dan formalin dalam bahan makanan jajanan seperti bakso, mie basah dan ikan asin yang beredar di pasaran. Hal ini diperkuat oleh sebuah penelitian di Kota Palembang yang menunjukkan bahwa dari sejumlah sampel yang diteliti, persentase sampel yang mengandung boraks adalah mie basah sebanyak $72 \%$, bakso sebanyak $70 \%$ dan empek-empek sebanyak $35 \%{ }^{3}$

Pengujian yang dilakukan oleh BPOM pada tahun 2003 pada berbagai jenis makanan di Indonesia seperti bakso, tahu, mie basah, ikan asin menunjukkan bahwa kandungan boraks dan formalin paling banyak ditemukan pada bakso. ${ }^{4}$

Pada tahun 2012 dilaporkan di Kota Medan didapati adanya kandungan boraks pada jajanan bakso, bahwa $80 \%$ dari sampel yang diperiksa ternyata mengandung boraks. Kadar boraks yang ditemukan berkisar antara 0,08-0,29\% dari berbagai lokasi yang diteliti. ${ }^{5}$

Badan Pengawasan Obat dan Makanan (BPOM) Palembang pada bulan Mei 2018 menemukan beragam jenis makanan yang mengandung boraks, formalin dan rhodamin. Selain itu BPOM Palembang menemukan sejumlah makanan yang mengandung formalin dan boraks di 12 pasar Bedug di Palembang. Paling mendominasi penggunakan bahan berbahaya boraks ini pada makanan rujak, mie dan tahu goreng. ${ }^{6}$

Dari hasil penelitian sebelumnya indicator dari ekstrak bunga sepatu yang diperoleh, menunjukkan perubahan warna yaitu dalam larutan asam berwarna merah dan dalam basa bewarna hijau. Perubahan warna ekstrak bunga sepatu dalam larutan asam dan basa disebabkan adanya antosianin. ${ }^{7}$

Ekstrak antosianin bunga sepatu ini dapat dimanfaatkan oleh masyarakat untuk mendeteksi dini boraks yang ada pada makanan yang beredar dimasyarakat, sehingga masyarakat lebih waspada dalam memilih makanan.

Ekstrak antosianin dari bunga kembang sepatu dapat digunakan sebagai indikator untuk identifikasi boraks. Dari penelitihan sebelumnya (Novitasari,2018) didapatkan hasil bahwa ekstraksi antosianin daribunga sepatu sebelum direaksikan memiliki warna oranye kecokelatan, dan ketika direaksikan dengan boraks berubah menjadi merah cokelat gelap. ${ }^{8}$

\section{METODE PENELITIAN}

\section{A. Definisi Operasional}

1. Ekstrak Antosianin adalah ekstrak yang didapatkan dari bunga kembang sepatu yang dapat mendeteksi boraks pada makanan

2. Bakso adalah Makanan berbahan dasar terigu dan daging yang diduga mengandung boraks.

\section{B. Desain Penelitian}

Desain penelitian yang digunakan adalah eksperimen atau percobaan. Bakso yang di dapatkan di Pasar Jakabaring Palembang Sumatera Selatan yang diuji dengan ekstrak antosianin bunga kembang sepatu, apabila reaksi perubahan warna ekstrak bunga kembang sepatu berubah warna menjadi warna merah coklat gelap berarti teridentifikasi boraks. 


\section{Peralatan dan Cara Kerja}

1. Alat
a. Cobek/ulekan/belender
b. Mangkok keramik
c. Tisu
d. Spatula/sendok
e. Pisau dan gunting
f. Pipet tetes
g. Tabung reaksi
h. Timbangan
i. Saringan

2. Bahan
a. Bunga kembang sepatu
b. Bakso
c. Air bersih
d. Etanol $96 \%$

3. Cara Kerja

a. Produser penelitian

Persiapan Bunga kembang sepatu

1. Pilih bunga kembang sepatu yang tua, berwarna merah segar.

2. Timbang bunga kembang sepatu sebanyak 50gr

3. Lalu bunga kemabang sepatu dicuci dan dipotong kecilkecil.

b. Persiapan pelarut

Pelarut yang di gunakan adalah etanol dengan konsentrasi sebesar $96 \%$ sebanyak $50 \mathrm{ml}$.

c. Proses ekstraksi

Ekstraksikan bunga kembang sepatu menggunakan metode ekstraksi maserasi untuk mendapatkan ekstrak antosianinnya. Sebanyak 50gr bunga kembang sepatu dan $50 \mathrm{ml}$ etanol dimasukan ke dalam gelas takar kemudian proses ekstraksi dilakukan selama $2 \times 24$ jam.

Setelah proses ekstraksi, saring larutan yang telah berubah warna menggunakan saring. Perubahan warna pada etanol 96\% menandakan bahwa antosianin pada bunga kembang sepatu telah terekstrak dan bercampur dengan pelarut.

d. Prosedur Pengujian Sampel Bakso

1. Siapkan rangkaian alat yang terdiri dari pisau, mangkok keramik, sendok, blander ekstrak bunga kembang sepatu dan sampel bakso.

2. Siapkan sampel bakso lalu haluskan menggunakan blander

3. Selanjutnya pindahkan potongan sampel yang sudah halus ke dalam tabung reaksi

4. Kemudian masukan media penguji ke tabung reaksi yang terdapat sampel uji tersebut

5. Langkah terakhir adalah menilai apakah perubahan warna yang terjadi dapat mengindentifikasikan ada atau tidaknya kandungan boraks pada sampel makanan selama 5 menit dan aduk sampel hingga tercampur dengan ekstrak tersebut.

\section{Pengolahan dan Analisis data}

Pengolahan dan analisis data dengan cara melihat dan mengamati hasil percobaan atau pengolahaan data secara deskriptif (gambaran) dengan melihat hasil dari perubahan warna pada bakso setelah ditetesi ekstrak antosianin bunga kembang sepatu. Apabila bakso berubah warna merah coklat gelap maka bakso dinyatakan positif mengandung boraks dan sebaliknya.

\section{HASIL DAN PEMBAHASAN}

Penelitian melakukan pengambilan sampel bakso sebanyak 3 sampel dari 3 penjual bakso yang berada di pasar Jakabaring Palembang Sumatera Selatan.

Bunga kembang sepatu yang tua, berwarna merah segar, sampel dicuci terlebih dahulu hingga bersih, dirobek kecil-kecil menggunakan tangan dan diekstrasi menggunakan metode maserasi 
menggunakan pelarut etanol $96 \%$ selama $2 \mathrm{x}$ 24 jam. Berdasarkan ekstraksi senyawa antosianin pada bunga kembang sepatu didapatkan hasil ekstrak larutan berwarna oranye kecoklatan (keungu-unguan).
Berdasarkan hasil pengujian reaksi perubahan warna ekstrak bunga kembang sepatu didapati hasil perubahan warna menjadi warna merah coklat gelap.

Tabel 1 Hasil Pengamatan

\begin{tabular}{|l|l|l|}
\hline $\begin{array}{l}\text { Jenis Ekstrak } \\
\text { antosianin }\end{array}$ & $\begin{array}{l}\text { Warna ekstrak sebelum } \\
\text { direaksikan dengan boraks }\end{array}$ & $\begin{array}{l}\text { Warna ekstrak setelah } \\
\text { direaksikan dengan boraks }\end{array}$ \\
\hline $\begin{array}{l}\text { Bunga Kembang } \\
\text { Sepatu }\end{array}$ & $\begin{array}{l}\text { Oranye kecoklatan } \\
\text { (keungu-unguan) }\end{array}$ & Merah coklat gelap \\
\hline
\end{tabular}

Keterangan (+)Positif, berubah warna merah coklat gelap

(-) Negatif, tidak berubah warna

Dari tabel 1 ekstrak yang digunakan adalah kelopak bunga kembang sepatu (Hibiscus rosa-sinensis.L) yang tua yang bewarna merah segar, sampel tersebut dicuci terlebih dahulu agar bersih, dirobek kecil-kecil, ditimbang sebanyak 50 gram dan diekstraksi dengan metode maserasi menggunakan pelarut etanol $96 \%$ selama 2 x 24 jam. Hasil yang didapat larutan berwarna oranye kecokelatan, yang mengekstrak pigmen antosianin bunga kembang sepatu dengan metode maserasi, hasil ekstraksi didpatkan larutan berwarna orange kecokelatan karena kandungan antosianin jenis pelagornidin, pelagornidin berperan dalam memberi warna oranye, oranye merah, hingga oranye cokelat. Untuk mengetahui apakah ekstrak antosianin dapat digunakan sebagai indikator untuk identifikasi boraks selanjutnya dilakukan pengujian hasil ekstraksi antosianin dari bunga kembang sepatu dengan bakso boraks yaitu dengan cara memasukkan 10 tetes hasil ekstraksi kedalam tabung reaksi yang berisikan bakso yang mengandung boraks, dan diamati hasil perubahan warnanya. Sebelum direaksikan warna ekstraksi antosianin berwarna oranye kecokelatan, ketika direaksikan dengan bakso yang mengandung boraks berubah menjadi merah cokelat gelap, hal ini akibat senyawa antosianin jenis pelagornidin bereaksi dengan senyawa boraks. Pada penelitian ini terlihat tidak ada warna bakso yang berekasi dengan ekstrak antosianin dan dinyatakan bebas dari pengawet.

\section{KESIMPULAN}

Berdasarkan hasil penelitian tentang pemanfaatan ekstrak bahan alami yang mengandung antosianin untuk identifikasi boraks, dapat diambil kesimpulan sebagai berikut : Ekstrak antosianin dari bunga kembang sepatu dapat digunakan sebagai indikator untuk identifikasi boraks. Hasil ekstraksi antosianin dari bunga kembang sepatu didapatkan larutan berwarna oranye kecokelatan. Sebelum direaksikan warna ekstraksi antosianin berwarna oranye kecokelatan (keungu-unguan), ketika diabsorsikan dengan bakso yang mengandung boraks berubah menjadi merah cokelat gelap.

\section{REFERENSI}

1. Murdiati Agnes dan Amaliah. 2013. Panduan Penyiapan Pangan Sehat Untuk Semua. Kencana Prenadamedia Group Jakarta.

2. Oktaviani Ira dan Yandra, A .2017. Bahaya Borak dan Cara Mengidentifikasi Makanan yang Mengandung Borak. Dinamisia-Jurnal 
pengabdian kepada masyarakat, Vol.1, No. 1, 24, 23-28.

3. Tumbel, M. 2010. Analisis Kandungan Boraks Dalam Mie Basah yang beredar di Kota Makassar Dosen Jurusan Kimia FMIPA UNM Makassar. Jurnal Chemica. Vo. 11 No.1.

4. Balai Pengawasan Obat dan Makanan. 2004, Bahan Tambahan Ilegal Boraks,Formalin Dan Rhodamin B, Jakarta, BPOM.

5. Https://www.viva.co.id/ berita/nasional/ 1039819 - menu - takjil - dipalembang mengandung-pengawet-mayat

6. Panjaitan, L. (2010). Pemeriksaan dan Penetapan Kadar Boraks dalam Bakso di Kota madya Medan. http://Repository.usu.ac.id/bitstream/123 456789/17273/ 7/Cover.pdf [18 Mei 2018].

7. Nuryanti Siti, dkk.2010. INDIKATOR TITRASI ASAM-BASA DARI EKSTRAK BUNGA SEPATU (Hibiscus rosa sinensis L). AGRITECH, Vol. 30, No. 3, Agustus2010. 8.Novitasari Eko. A dan Barik Zidni.A. 2018.Pemanfaatan Ekstrak antosianin dari Bunga Kembang Sepatu (Hibiscusrosa sinensis.L) Sebagai Indikator untuk Identifikasi Boraks. Jurnal Sains, Vol.8, No.16,9,18-15. ISSN2087-0725.

9. Wibowo.2006.Dalam Sitompul Erwin .2018. Penambahan Tepung Aren dan Guar Gum Terhadap Kualitas Fisik Bakso. Simki-Techsain Vol. 02 No. 07 ISSN : 2599-301[Skiprsi]

10. Badan Standarisasi Nasional Indonesia. 1995, SNI 01-3818-1995, tentang Bakso Daging, Jakarta, Badan Standarisasi Nasional.

11. Pandie Thedyastry, dkk .2014. Identifikasi Boraks, Formalin dan Kandungan Gizi serta Nilai Tipe pada Bakso yang Dijual di Lingkungan Perguruan Tinggi di Kota Kupang. Jurnal Kajian Veteriner, Vol. 2 No. 2 : 183-192. ISSN : 2356-4113.
12. Depkes, Permenkes RI Nomor 033 Tahun 2012, Bahan Tambahan Pangan.

13. Depkes, Permenkes RI, No. $722 /$ Menkes/Per/X/1999, Bahan Tambahan Pangan (Jakarta : Depkes RI. 1999)

14. Tubagus, Indra dkk.2013. Identifikasi dan Penetapan Kadar Boraks dalam Bakso Jajanan di kota Manado. Pharmacon Jurnal Ilmiah Farmasi UNSRAT, Vol.2, No.4,143,142-148. ISSN2302-2493.

15. Undang-Undang Nomor 18 Tahun 2012 tentang Pangan, Pasal 136.

16. Agustina, Dina dan Ismiyati .2015. Pengaruh Konsentrasi Pelarut Pada Proses EkstraksiAntosianin Dari Bunga Kembang Sepatu.KONVERS. Vol.4.No.2. ISSN2252-7311

17. Balai Pengawasan Obat dan Makanan. 2004, Bahan Tambahan Ilegal Boraks,Formalin Dan Rhodamin B, Jakarta, BPOM.

18. Balai Pengawasan Obat dan Makanan. 2004, Bahan Tambahan Ilegal Boraks, Formalin Dan Rhodamin B, Jakarta, BPOM.

19. Yusraini, D.I.S \& Nurlela .2011. Ekstraksi dan Uji Stabilitas Zat Warna Alami dari Bunga Kembang Sepatu (Hibiscus rosa-sinensis L) dan Bunga Rosela (Hibiscus sabdariffa L).Valensi Vol. 2 No. 3, Nop 2011 (459-467). ISSN :1978 - 8193 .

20. Nuryanti Siti, dkk.2010. INDIKATOR TITRASI ASAM-BASA DARI EKSTRAK BUNGA SEPATU (Hibiscus rosa sinensis L). AGRITECH, Vol. 30, No. 3, Agustus2010.

21. Riniati et al., Ind. J. Chem. Anal.2019. Ekstraksi Kembang sepatu (Hibiscus Rosa Sinensis L)Menggunakan Pelarut Metanol dengan Metode Sokletasi untuk Indikator Titrasi Asam Bas, Indonesian Journal of Chemical Analysis, Vol. 02, No 01, 2019, pp. 34-40.ISSN 26227401, e ISSN 2622-7126 